\title{
Effects of simvastatin and fenofibrate on butyrylcholinesterase activity in the brain, plasma, and liver of normolipidemic and hyperlipidemic rats
}

\author{
Antonija Vukšić ${ }^{1}$, Jasna Lovrić ${ }^{2}$, Paško Konjevoda ${ }^{3}$, Nina Blažević ${ }^{1}$, Marinko Bilušić ${ }^{4}$, and \\ Vlasta Bradamante ${ }^{1}$ \\ ${ }^{1}$ University of Zagreb, School of Medicine, Department of Pharmacology, Zagreb, Croatia \\ ${ }^{2}$ University of Zagreb, School of Medicine, Department of Medical Chemistry, Biochemistry, and Clinical Chemistry, \\ Zagreb, Croatia \\ ${ }^{3}$ Ruđer Bošković Institute, NMR Centre, Zagreb, Croatia \\ ${ }^{4}$ Polyclinic Bonifarm, Department of Clinical Pharmacology and Toxicology, Zagreb, Croatia
}

[Received in October 2018; Similarity Check in October 2018; Accepted in February 2019]

The study objective was to test the hypothesis that simvastatin and fenofibrate should cause an increase in butyrylcholinesterase (BuChE) activity not only in the plasma and liver but also in the brain of normolipidemic and hyperlipidemic rats. Catalytic enzyme activity was measured using acetylthiocholine (ATCh) and butyrylthiocholine (BTCh) as substrates. Normolipidemic and hyperlipidemic rats were divided in four groups receiving $50 \mathrm{mg} / \mathrm{kg}$ of simvastatin a day or $30 \mathrm{mg} / \mathrm{kg}$ of fenofibrate a day for three weeks and three control groups receiving saline. Simvastatin and fenofibrate caused an increase in brain BuChE activity in both normo- and hyperlipidemic rats regardless of the substrate. The increase with BTCh as substrate was significant and practically the same in normolipidemic and hyperlipidemic rats after simvastatin treatment (14-17\% vs controls). Simvastatin and fenofibrate also increased liver and plasma BuChE activity in both normolipidemic and hyperlipidemic rats regardless of the substrate. In most cases the increase was significant. Considering the important role of BuChE in cholinergic transmission as well as its pharmacological function, it is necessary to continue investigations of the effects of lipid-lowering drugs on BuChE activity.

KEY WORDS: acetylthiocoline; butyrylthiocholine; lipid-lowering drugs; Wistar rats; Zucker rats

Butyrylcholinesterase (BuChE), also known as pseudocholinesterase $(\mathrm{PChE})$ and plasma cholinesterase (EC 3.1.1.8), is synthesised in the liver and secreted into the blood circulation $(1,2)$. BuChE is found in the blood, pancreas, liver, central nervous system, and other tissues, but its function and endogenous substrate have not yet been established (3). Some authors propose that increased plasma $\mathrm{BuChE}$ activity in humans is associated with an abnormal lipid metabolism $(1,2,4,5)$. This enzyme is biochemically related to acetylcholinesterase (AChE, EC 3.1.1.7), and although it is less substrate-specific for acetylcholine (ACh) than $\mathrm{AChE}, \mathrm{BuChE}$ is the major ACh-hydrolysing enzyme in the circulation (6). In the brain, $\mathrm{BuChE}$ is involved in ACh hydrolysis together with AChE and serves as a coregulator of cholinergic transmission. BuChE also hydrolyses a variety of other choline esters including butyrylcholine $(\mathrm{BCh})$, propionylcholine, succinylcholine, and the aminoester local anaesthetics. According to new research (7), this enzyme is also involved in the degradation

Corresponding author: Vlasta Bradamante, Department of Pharmacology, University of Zagreb School of Medicine, Šalata 11, 10000 Zagreb, Croatia, e-mail: vbradam@mef.hr of ghrelin, a hormone responsible for the sensation of hunger.

Different drugs may either decrease or increase the activity of BuChE and AChE. Inhibition of plasma BuChE in rats and humans may be caused by organophosphorus herbicides such as glyphosate (8), reversible cholinesterase inhibitors (9), glucocorticoids $(10,11)$, or some beta blockers (12). In humans, low plasma BuChE activity may reduce succinylcholine hydrolysis and prolong respiratory depression (13). In contrast, brain inhibition of BuChE and AChE activity may be beneficial for the therapy of older population, as the inhibitors of both enzymes enhance the activity of cholinergic neurons in the brain, which is of particular benefit in patients with Alzheimer's disease, who have decreased forebrain cholinergic neuron count and a progressive decrease in ACh $(14,15)$.

Like many other, lipid-lowering drugs affect enzyme activity. Several in vitro and in vivo non-clinical investigations have evidenced that statins either decrease or have no effect on AChE and BuChE activity $(16,17)$. Our recent study, however, has shown that simvastatin significantly increases plasma and liver BuChE activity in normolipidemic rats (18). Fibrates have also been shown 
to increase BuChE activity in non-clinical studies $(19,20)$ Clinical evidence, in turn, is still not strong enough to reach definitive conclusions about the effects of lipid-lowering agents on plasma BuChE activity $(4,21)$.

Because of the pharmacological function of BuChE in plasma, its role in the brain cholinergic system, and the widespread therapeutic use of lipid-lowering drugs, we extended our investigation to include the effect of lipidlowering agents on brain BuChE activity and test the hypothesis that they should increase brain BuChE activity like they do in the plasma and liver. Simvastatin and fenofibrate as representatives of statins and fibric acid derivatives were chosen for this investigation because both agents cross the blood-brain barrier. We also wanted to see if the increase in brain, plasma, and liver enzyme activity would be greater in hyperlipidemic rats.

\section{MATERIALS AND METHODS}

\section{Test substances}

Simvastatin (CAS-79902-63-9) (Lipex $^{\circledR}$, Merck Sharp $\&$ Dohme, Haarlem, the Netherlands) and fenofibrate (CAS49562-28-9) (Tricor ${ }^{\circledR}$, Recipharm Fontaine, Fontaine-lèsDijon, France) tablets were suspended in $5 \mathrm{~mL} / \mathrm{kg}$ saline and administered daily between 9.00 and 10.00 a.m. by oral gavage.

\section{Animals}

Normolipidemic Wistar rats weighing 250-300 g were obtained from the Department of Pharmacology, University of Zagreb School of Medicine, Croatia, whereas the hyperlipidemic Zucker rats (HsdOla: Zucker-Lepr fa-fa) weighing 270-300 g were obtained from Harlan Laboratories srl., Udine, Italy. The animals were kept under controlled laboratory conditions and receiving standard pelleted diet ad libitum. Handling and treatment followed the FELASA guidelines and recommendations for the use of laboratory animals (22). The experiments had been approved by the local committee of the Zagreb University School of Medicine.

\section{Study design}

Normolipidemic rats were randomly divided in two experimental $(\mathrm{N}=10$ each) and two control groups $(\mathrm{N}=8$ each). One experimental group received $50 \mathrm{mg} / \mathrm{kg}$ of simvastatin a day and the other $30 \mathrm{mg} / \mathrm{kg}$ of fenofibrate a day. Control groups received $0.9 \% \mathrm{NaCl}$ solution, as it was solvent for drugs in the experimental groups. The route of administration was the same as in the experimental groups (oral gavage). Hyperlipidemic Zucker rats were also randomly divided in two experimental and one control group. One experimental group $(\mathrm{N}=7)$ received simvastatin and the other $(\mathrm{N}=8)$ fenofibrate in the same doses and way as the normolipidemic rats. The control group $(\mathrm{N}=6)$ received saline as above.

The experimental treatment lasted 21 days. On day 22 , after a 12-hour overnight fast, all animals were sacrificed under diethyl ether anaesthesia (23). Blood samples for the measurement of $\mathrm{BuChE}$ activity were obtained by cardiac puncture and frozen at $-20^{\circ} \mathrm{C}$ immediately after sampling until further processing. Liver and brain tissue for the determination of BuChE activity was frozen at $-70{ }^{\circ} \mathrm{C}$. Before collecting, blood was washed from the liver with saline in situ through the superior vena cava. The brain was also rinsed with saline.

Measurement of BuChE activity in the brain, plasma, and liver

The catalytic activity of BuChE in the brain, plasma, and liver was measured spectrophotometrically as described by Ellman et al. (24) using butyrylthiocholine (BTCh) $(0.9 \mathrm{mmol} / \mathrm{L})$ and acetylthiocholine $(\mathrm{ATCh})(0.6 \mathrm{mmol} / \mathrm{L})$ as substrates (Sigma ChemCo, St. Louis, MO, USA). Whole brains weighing 1.8 to $2.2 \mathrm{~g}$ and small portions of liver weighing 0.7 to $0.98 \mathrm{~g}$ were homogenised in four volumes of saline and centrifuged at $3500 \times \mathrm{g}$ for $15 \mathrm{~min}$. The reaction mixture for the hydrolysis in the brain, plasma, and liver contained $1 \mathrm{~mL}$ of a mixture of $3 \mathrm{~mL} 0.1 \mathrm{~mol}$ phosphate buffer and $100 \mu \mathrm{L}$ of $0.38 \mathrm{mmol} / \mathrm{L} 5.5$-dithio-bis (2-nitrobenzoic acid) (DTNB), $100 \mu \mathrm{L}$ of BTCh or $100 \mu \mathrm{L}$ of ATCh, and $50 \mu \mathrm{L}$ of plasma or $50 \mu \mathrm{L}$ of brain or liver homogenate. The reaction for the measurement of $\mathrm{BuChE}$ activity in the liver tissue was repeated after the addition of $50 \mu \mathrm{L}$ of ethopropazine hydrochloride, which is a specific BuChE inhibitor. The increase in absorbance at $412 \mathrm{~nm}$ and at $25{ }^{\circ} \mathrm{C}$ was monitored for 3 min. A blank sample containing the incubation mixture without the brain, plasma, and liver homogenate was run simultaneously to correct for the spontaneous substrate breakdown. Enzyme activities were expressed as $\mu \mathrm{mol} / \mathrm{L}$ of substrate hydrolysed per min per $\mathrm{mL}$ of plasma or $\mathrm{g}$ of tissue.

\section{Data analysis}

Data were analysed using Dunnett's multiple comparison test, which compares treatment groups with controls (25). All tests were two-tailed, and the P values of $<0.05$ were considered statistically significant. All calculations and data plotting were done using GraphPad Prism for Windows version 7 (GraphPad Software, San Diego, CA, USA).

\section{RESULTS AND DISCUSSION}

\section{Brain, plasma, and liver BuChE activity in normolipidemic rats}

Table 1 shows brain, plasma, and liver BuChE activity in normolipidemic rats. Brain BuChE activity measured with ATCh was not significantly affected by simvastatin 
Table 1 Effects of simvastatin ( $50 \mathrm{mg} / \mathrm{kg}$ daily for three weeks) and fenofibrate (30 mg/kg daily for three weeks) on brain, plasma, and liver BuChE activity in normolipidemic rats, measured with ATCh and BTCh as substrates

\begin{tabular}{|c|c|c|c|c|c|c|c|}
\hline Substrate & Variable & Control $^{\mathbf{a}}$ & $\begin{array}{l}\text { Simvastatin }^{a} \\
(50 \mathrm{mg} / \mathrm{kg} / \text { day })\end{array}$ & $\begin{array}{l}\text { P Value } \\
(95 \% \text { CI })^{c}\end{array}$ & Control $^{\mathrm{a}}$ & $\begin{array}{c}\text { Fenofibrate } \\
(30 \mathrm{mg} / \mathrm{kg} / \\
\text { day })\end{array}$ & $\begin{array}{l}\text { P Value }^{b} \\
(95 \% \text { CI })^{c}\end{array}$ \\
\hline \multirow{3}{*}{ ATCh } & $\begin{array}{l}\text { BuChE brain } \\
(\mu \mathrm{mol} / \mathrm{min} / \mathrm{g})\end{array}$ & $\begin{array}{c}0.29 \pm 0.018 \\
\quad(\mathrm{n}=8)\end{array}$ & $\begin{array}{c}0.28 \pm 0.006 \\
\quad(\mathrm{n}=8)\end{array}$ & $\begin{array}{c}0.477 \\
(-0,019 \text { to } \\
0,009)\end{array}$ & $\begin{array}{c}0.37 \pm 0.035 \\
\quad(\mathrm{n}=8)\end{array}$ & $\begin{array}{c}0.35 \pm 0.016 \\
\quad(n=8)\end{array}$ & $\begin{array}{c}0.412 \\
(-0.047 \text { to } \\
0.021)\end{array}$ \\
\hline & $\begin{array}{l}\text { BuChE plasma } \\
(\mu \mathrm{mol} / \mathrm{min} / \mathrm{mL})\end{array}$ & $\begin{array}{c}0.31 \pm 0.063 \\
\quad(n=8)\end{array}$ & $\begin{array}{c}0.38 \pm 0.048 \\
\quad(n=7)\end{array}$ & $\begin{array}{c}\mathbf{0 . 0 2 9} \\
(0.009 \text { to } \\
0.134)\end{array}$ & $\begin{array}{c}0.25 \pm 0.049 \\
\quad(n=7)\end{array}$ & $\begin{array}{c}0.37 \pm 0.073 \\
\quad(n=8)\end{array}$ & $\begin{array}{c}\mathbf{0 . 0 0 3} \\
(0.051 \text { to } \\
0.195)\end{array}$ \\
\hline & $\begin{array}{l}\text { BuChE liver } \\
(\mu \mathrm{mol} / \mathrm{min} / \mathrm{g})\end{array}$ & $\begin{array}{c}0.58 \pm 0.165 \\
\quad(n=8)\end{array}$ & $\begin{array}{c}0.69 \pm 0.207 \\
\quad(n=7)\end{array}$ & $\begin{array}{c}0.263 \\
(-0.095 \text { to } \\
0.319)\end{array}$ & $\begin{array}{c}0.47 \pm 0.243 \\
\quad(n=6)\end{array}$ & $\begin{array}{c}0.86 \pm 0.150 \\
\quad(n=5)\end{array}$ & $\begin{array}{c}\mathbf{0 . 0 1 3} \\
(0.106 \text { to } \\
0.674)\end{array}$ \\
\hline \multirow{3}{*}{ BTCh } & $\begin{array}{l}\text { BuChE brain } \\
(\mu \mathrm{mol} / \mathrm{min} / \mathrm{g})\end{array}$ & $\begin{array}{c}0.06 \pm 0.009 \\
\quad(n=8)\end{array}$ & $\begin{array}{c}0.07 \pm 0.002 \\
\quad(\mathrm{n}=8)\end{array}$ & $\begin{array}{c}\mathbf{0 . 0 4 3} \\
(0.001 \text { to } \\
0.014)\end{array}$ & $\begin{array}{c}0.08 \pm 0.006 \\
(\mathrm{n}=8)\end{array}$ & $\begin{array}{c}0.09 \pm 0.003 \\
\quad(n=8)\end{array}$ & $\begin{array}{c}0.167 \\
(-0.002 \text { to } \\
0.009)\end{array}$ \\
\hline & $\begin{array}{l}\text { BuChE plasma } \\
(\mu \mathrm{mol} / \mathrm{min} / \mathrm{mL})\end{array}$ & $\begin{array}{c}0.07 \pm 0.010 \\
\quad(\mathrm{n}=8)\end{array}$ & $\begin{array}{c}0.11 \pm 0.005 \\
\quad(\mathrm{n}=8)\end{array}$ & $\begin{array}{c}<\mathbf{0 . 0 0 1} \\
(0.022 \text { to } \\
0.049)\end{array}$ & $\begin{array}{c}0.08 \pm 0.014 \\
\quad(\mathrm{n}=8)\end{array}$ & $\begin{array}{c}0.13 \pm 0.038 \\
\quad(n=6)\end{array}$ & $\begin{array}{c}\mathbf{0 . 0 0 3} \\
(0.022 \text { to } \\
0.085)\end{array}$ \\
\hline & $\begin{array}{l}\text { BuChE liver } \\
(\mu \mathrm{mol} / \mathrm{min} / \mathrm{g})\end{array}$ & $\begin{array}{c}0.79 \pm 0.292 \\
\quad(\mathrm{n}=6)\end{array}$ & $\begin{array}{c}0.82 \pm 0.177 \\
(\mathrm{n}=5)\end{array}$ & $\begin{array}{c}0.871 \\
(-0.314 \text { to } \\
0.364)\end{array}$ & $\begin{array}{c}0.41 \pm 0.284 \\
\quad(n=8)\end{array}$ & $\begin{array}{l}0.76 \pm 0.115 \\
\quad(n=7)\end{array}$ & $\begin{array}{c}\mathbf{0 . 0 0 9} \\
(0.108 \text { to } \\
0.606)\end{array}$ \\
\hline
\end{tabular}

Bolded P values are significant at the $<0.05$ level; ATCh - acetylthiocholine, BTCh - butyrylthiocholine, BuChE - butyrylcholinesterase; ${ }^{\mathrm{a}}$ values are mean $\pm \mathrm{SD} ;{ }^{b} \mathrm{P}$ value of independent two-sample t-test; ${ }^{\mathrm{c}} 95 \%$ confidence interval for difference between means

and fenofibrate. In plasma its activity increased $22 \%$ $(\mathrm{p}=0.029)$ with simvastatin and $48 \%(\mathrm{p}=0.003)$ with fenofibrate vs control (Table 1). In the liver BuChE catalytic activity soared $83 \%$ ( $\mathrm{p}=0.013$ ) with fenofibrate vs control, while the increase of $19 \%$ with simvastatin was not statistically significant (Table 1).

When BTCh was used as substrate, simvastatin increased brain BuChE activity 17\% vs control ( $\mathrm{p}=0.043$ ), and fenofibrate caused only mild changes. In the plasma, BuChE activity increased $57 \%$ with simvastatin $(\mathrm{p}<0.001)$ and $63 \%$ with fenofibrate $(\mathrm{p}=0.003)$. Liver BuChE activity increased $85 \%(p=0.009)$ with fenofibrate, while simvastatin caused only a mild increase.

\section{Brain, plasma, and liver BuChE activity in hyperlipidemic rats}

Table 2 shows brain, plasma, and liver BuChE activity in hyperlipidemic rats. Measured with ATCh as substrate brain BuChE activity increased $18 \%$ vs control $(\mathrm{p}=0.008)$ with simvastatin and $7 \%$ with fenofibrate $(p>0.05)$. Plasma BuChE activity increased $56 \%(\mathrm{p}<0.001)$ and $84 \%$ $(\mathrm{p}<0.001)$, whereas liver $\mathrm{BuChE}$ activity increased $40 \%$ $(p<0.001)$ and $59 \%(p<0.001)$ vs control, respectively.

With BTCh used as substrate brain BuChE activity increased $14 \%(p<0.001)$ with both simvastatin and fenofibrate. Plasma BuChE activity increased 94\% with simvastatin and as high as $144 \%$ with fenofibrate $(\mathrm{p}<0.001)$, whereas liver BuChE activity increased 103\% $(\mathrm{p}=0.003)$ with simvastatin and only $26 \%$ with fenofibrate $(p>0.05)$.
Our results confirm our hypothesis that simvastatin and fenofibrate would increase brain BuChE activity in both normolipidemic and hyperlipidemic rats regardless of the type of substrate used to measure enzyme activity. The exception is brain BuChE activity in normolipidemic rats when ATCh was used as substrate. The reason is higher affinity of BuChE for BTCh than for ATCh, i.e. the enzyme is less substrate-specific for ACh. Since BuChE is biochemically related to AChE, we believe that this difference in substrate sensitivity is not an obstacle to interpret our results in light of reports of AChE activity. Cibicková et al. (17) were the first to show the inhibitory effect of simvastatin and atorvastatin on brain AChE activity in the frontal cortex of rats. Their second study (26), in contrast, found no change in brain AChE activity. Dalla et al. (27) also reported that simvastatin and pitavastatin had no effect on brain AChE activity in rats on normal diet. These studies and our investigations suggest that statins have different effect on BuChE and $\mathrm{AChE}$ activity.

We cannot, however, interpret the fenofibrate-induced increase in brain BuChE activity in light of other studies, as none have been published so far. Fenofibrate showed similar effects to simvastatin on brain BuChE activity, i.e. increase in its activity, as it causes a faster hydrolysis of $\mathrm{ACh}$ and consequently affects brain cholinergic transmission. In patients on long-term statin or fibrate therapy, the increase in brain BuChE activity could therefore cause side effects.

Simvastatin and fenofibrate in our study also caused higher liver and plasma BuChE activity in both rat strains regardless of the used substrate (Tables 1 and 2), but the 
Table 2 Effects of simvastatin (50 mg/kg daily for three weeks) and fenofibrate (30 mg/kg daily for three weeks) on brain, plasma, and liver BuChE activity in hyperlipidemic rats, measured with ATCh and BTCh as substrates

\begin{tabular}{|c|c|c|c|c|c|c|}
\hline Substrate & Variable & Control $^{a}$ & $\begin{array}{l}\text { Simvastatin }^{a} \\
(50 \mathrm{mg} / \mathrm{kg} / \text { day })\end{array}$ & $\begin{array}{c}\text { P Value }^{\mathrm{b}} \\
(95 \% \text { CI })^{\mathrm{c}}\end{array}$ & $\begin{array}{c}\text { Fenofibrate }^{a} \\
(30 \mathrm{mg} / \mathrm{kg} / \text { day })\end{array}$ & $\begin{array}{l}\text { P Value } \\
(95 \% \text { CI })^{\text {c }}\end{array}$ \\
\hline \multirow{3}{*}{ ATCh } & $\begin{array}{l}\text { BuChE brain } \\
(\mu \mathrm{mol} / \mathrm{min} / \mathrm{g})\end{array}$ & $\begin{array}{c}0.27 \pm 0.020 \\
\quad(\mathrm{n}=6)\end{array}$ & $\begin{array}{c}0.32 \pm 0.038 \\
\quad(\mathrm{n}=6)\end{array}$ & $\begin{array}{c}\mathbf{0 . 0 0 8} \\
(-0.079 \text { to } \\
-0.012)\end{array}$ & $\begin{array}{l}0.29 \pm 0.005 \\
\quad(\mathrm{n}=7)\end{array}$ & $\begin{array}{c}0.272 \\
(-0.052 \text { to } \\
0.013)\end{array}$ \\
\hline & $\begin{array}{l}\text { BuChE plasma } \\
(\mu \mathrm{mol} / \mathrm{min} / \mathrm{mL})\end{array}$ & $\begin{array}{l}0.43 \pm 0.025 \\
\quad(\mathrm{n}=6)\end{array}$ & $\begin{array}{c}0.67 \pm 0.096 \\
\quad(\mathrm{n}=6)\end{array}$ & $\begin{array}{c}<\mathbf{0 . 0 0 1} \\
(-0.363 \text { to } \\
-0.104)\end{array}$ & $\begin{array}{c}0.79 \pm 0.118 \\
\quad(\mathrm{n}=8)\end{array}$ & $\begin{array}{c}<\mathbf{0 . 0 0 1} \\
(-0.475 \text { to } \\
-0.233)\end{array}$ \\
\hline & $\begin{array}{l}\text { BuChE liver } \\
(\mu \mathrm{mol} / \mathrm{min} / \mathrm{g})\end{array}$ & $\begin{array}{c}1.85 \pm 0.237 \\
\quad(\mathrm{n}=6)\end{array}$ & $\begin{array}{l}2.60 \pm 0.152 \\
\quad(\mathrm{n}=6)\end{array}$ & $\begin{array}{c}<\mathbf{0 . 0 0 1} \\
(-1.044 \text { to } \\
-0.459)\end{array}$ & $\begin{array}{l}2.95 \pm 0.226 \\
\quad(\mathrm{n}=8)\end{array}$ & $\begin{array}{c}<\mathbf{0 . 0 0 1} \\
(-1.376 \text { to } \\
-0.828)\end{array}$ \\
\hline \multirow{3}{*}{ BTCh } & $\begin{array}{l}\text { BuChE brain } \\
(\mu \mathrm{mol} / \mathrm{min} / \mathrm{g})\end{array}$ & $\begin{array}{l}0.07 \pm 0.004 \\
\quad(\mathrm{n}=6)\end{array}$ & $\begin{array}{c}0.08 \pm 0.006 \\
\quad(\mathrm{n}=5)\end{array}$ & $\begin{array}{c}<\mathbf{0 . 0 0 1} \\
(-0.021 \text { to } \\
-0.009)\end{array}$ & $\begin{array}{c}0.08 \pm 0.003 \\
\quad(\mathrm{n}=8)\end{array}$ & $\begin{array}{c}<\mathbf{0 . 0 0 1} \\
(-0.018 \text { to } \\
-0.007)\end{array}$ \\
\hline & $\begin{array}{l}\text { BuChE plasma } \\
(\mu \mathrm{mol} / \mathrm{min} / \mathrm{mL})\end{array}$ & $\begin{array}{c}0.16 \pm 0.011 \\
\quad(n=6)\end{array}$ & $\begin{array}{l}0.31 \pm 0.043 \\
\quad(\mathrm{n}=6)\end{array}$ & $\begin{array}{c}<\mathbf{0 . 0 0 1} \\
(-0.203 \text { to } \\
-0.079)\end{array}$ & $\begin{array}{c}0.39 \pm 0.06 \\
(\mathrm{n}=8)\end{array}$ & $\begin{array}{c}<\mathbf{0 . 0 0 1} \\
(-0.287 \text { to } \\
-0.172)\end{array}$ \\
\hline & $\begin{array}{l}\text { BuChE liver } \\
(\mu \mathrm{mol} / \mathrm{min} / \mathrm{g})\end{array}$ & $\begin{array}{c}0.38 \pm 0.193 \\
\quad(n=6)\end{array}$ & $\begin{array}{c}0.77 \pm 0.147 \\
\quad(\mathrm{n}=6)\end{array}$ & $\begin{array}{c}\mathbf{0 . 0 0 3} \\
(-0.646 \text { to } \\
-0.148)\end{array}$ & $\begin{array}{c}0.48 \pm 0.189 \\
\quad(\mathrm{n}=8)\end{array}$ & $\begin{array}{c}0.455 \\
(-0.339 \text { to } \\
0.127)\end{array}$ \\
\hline
\end{tabular}

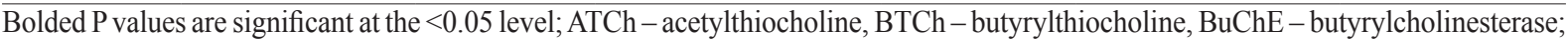
${ }^{\mathrm{a}}$ values are mean $\pm \mathrm{SD} ;{ }^{b} \mathrm{P}$ value of independent two-sample t-test; ${ }^{\mathrm{c}} 95 \%$ confidence interval for difference between means

effect was mostly stronger in hyperlipidemic rats. In some cases BuChE activity was higher when BTCh was used as substrate (Table 1), especially in hyperlipidemic rats (Table 2). A possible reason why simvastatin and fenofibrate should cause higher enzyme activity in the plasma and liver of hyperlipidemic rats is their pathophysiological condition.

Higher BuChE activity in this study confirms our previous findings for simvastatin and gemfibrozil, the other member of fibric acid derivatives, as well as the results reported by other authors who showed that clofibrate, gemfibrozil, and fenofibrate significantly increased serum and liver BuChE activity in rats and mice (28-30). In contrast, Cibicková et al. (26) did not prove any influence of simvastatin and atorvastatin on either $\mathrm{AChE}$ or $\mathrm{BuChE}$ in the blood.

The significant increase in liver and plasma BuChE activity caused by simvastatin and fenofibrate is likely a consequence of the higher expression of peroxisome proliferator-activated receptor alpha $(\operatorname{PPAR} \alpha)$, which is a well known transcriptional factor (31-33). In rodents PPAR $\alpha$ is primarily expressed in the liver and adipose tissue and, to a lesser extent, in the kidney, heart, and skeletal muscles. It plays an important role in lipid homeostasis, as it influences fatty acid metabolism and its activation lowers lipid levels in animals and humans (34-36).

According to Ferreira et al. (37), fenofibrate treatment increased PPAR alpha and gamma receptors in rat adipose tissue and in consequence of their activation also increased the expression of some oxidative enzymes. It had the same effect on oxidative enzymes in rat liver (37-39). This suggests that the activation of PPAR $\alpha$ receptor also stands behind fenofibrate increasing $\mathrm{BuChE}$ expression in the liver.

PPAR $\alpha$ receptors have recently been reported in some brain regions, where they probably have an important role in brain lipid metabolism $(40,41)$. Berger et al. (42) have also suggested that specific fatty acids that play a crucial role in neural cells and are essential components of myelin are synthesised in peroxisomes. Further research should answer whether higher brain $\mathrm{BuChE}$ activity in our study is partly owed the agonistic effects of simvastatin and fenofibrate on brain PPAR $\alpha$ receptors and on these special fatty acids.

It is known for a fact that rodents are more susceptible to peroxisome proliferators than dogs, rhesus monkeys, or humans. Probably this difference in PPAR $\alpha$ receptor sensitivity to statins and fibrates is the reason why statins either do not affect or lower plasma enzyme activity in humans $(4,21,43)$.

Clinical investigations referred to above lasted no longer than six months, which begs the question whether long-term lipid-lowering therapy could change the sensitivity of PPAR $\alpha$ and cause an increase rather than a decrease in BuChE activity in human patients.

In summary, our results clearly show that simvastatin and fenofibrate cause a similar increase in brain BuChE activity in normolipidemic and hyperlipidemic rats. Such increases in brain BuChE activity could lead to side effects in patients on long-term therapy with statins and fibrates. We have also verified our earlier findings that simvastatin and fibric acid derivatives increase liver and plasma $\mathrm{BuChE}$ activity. However, it is hard to extrapolate our findings in 
humans at this point, because rats are more susceptible to peroxisome proliferators than humans. Future pre-clinical research should therefore focus on the molecular mechanisms of these changes. Because of the pharmacological role of BuChE in plasma and brain cholinergic system, long-term clinical studies are also needed to elucidate the impact of statins and fibrates on BuChE activity.

\section{Conflicts of interests}

None to declare.

\section{Acknowledgements}

We gratefully acknowledge the expert technical assistance of Željka Roca. We also wish to thank Aleksandra Žmegač Horvat for help with the language. This study was supported by the Ministry of Science, and Education of the Republic of Croatia, Grant No. 108-0000000-0013.

\section{REFERENCES}

1. Clitherow JW, Mitchard M, Harper NJ. The possible biological function of pseudo-cholinesterase. Nature 1963;199:1000-1. doi:10.1038/1991000a0

2. Kutty KM. Biological function of cholinesterase. Clin Biochem 1980;13:239-43. doi: 10.1016/S0009. 9120(80)80001-4

3. Giacobini E. Cholinesterase inhibitors: new roles and therapeutic alternatives. Pharmacol Res 2004;50:433-50. doi: 10.1016/j.phrs.2003.11.017

4. Rustemeijer C, Schouten JA, Voerman HJ, Beynen AC, Donker AJ, Heine RJ. Is pseudocholinesterase activity related to markers of triacalglycerol synthesis in type II diabetes mellitus? Clin Sci (Lond) 2001;101:29-35. doi: 10.1042/ cs 1010029

5. Kálmán J, Juhász A, Rakonczay Z, Abrahám G, Zana M, Boda K, Farkas T, Penke B, Janka Z. Increased serum butyrylcholinesterase activity in type IIb hyperlipidaemic patients. Life Sci 2004;75:1195-204. doi: 10.1016/j. 1fs.2004.02.019

6. Cokuğraş AN. Butyrylcholinesterase: structure and physiological importance. Turk J Biochem 2003;28:54-61.

7. Chen VP, Gao Y, Geng L, Brimijoin S. Butyrylcholinesterase regulates central ghrelin signaling and has an impact on food intake and glucose homeostasis. Int J Obes (Lond) 2017;41:1413-9. doi: 10.1038/ijo.2017.123

8. Milić M, Žunec S, Micek V, Kašuba V, Mikolić A, Lovaković BT, Semren TŽ, Pavičić I, Marjanović Čermak AM, Pizent A, Lucić Vrdoljak A, Valencia-Quintana R, Sánchez-Alarcón J, Želježić D. Oxidative stress, cholinesterase activity, and DNA damage in the liver, whole blood, and plasma of Wistar rats following a 28-day exposure to glyphosate. Arh Hig Rada Toksikol 2018;69:154-68. doi: 10.2478/aiht-2018-69-3114

9. Pohanka M. Inhibitors of acetylcholinesterase and butyrylcholinesterase meet immunity. Int J Mol Sci 2014;15:9809-25. doi: 10.3390/ijms15069809

10. Lucić Vrdoljak A, Bradamante V, Radić B, Peraica M, Fuchs $\mathrm{R}$, Reiner Z. Butyrylcholinesterase activity and plasma lipids in dexamethasone treated rats. Acta Pharm 2005;55:177-85. PMID: 16179131

11. Bradamante V, Kunec-Vajić E, Lisić M, Dobrić I, Beus I. Plasma cholinesterase activity in patients during therapy with dexamethasone or prednisone. Eur J Clin Pharmacol 1989;36:253-7. doi: 10.1007/BF00558156

12. Barabas E, Zsigmond EK, Kirkpatrick AF. The inhibitory effect of esmolol on human plasmacholinesterase. Can Anaesth Soc J 1986;33:332-5. doi: 10.1007/BF03010746

13. Feldman S, Karalliedde L. Drug interactions with neuromuscular blockers. Drug Saf 1996;15:261-73. doi: 10.2165/00002018-199615040-00004

14. Geula C, Darvesh S. Butyrylcholinesterase, cholinergic neurotransmission and the pathology of Alzheimer's disease. Drugs Today (Barc) 2004;40:711-21. doi: 10.1358/ dot.2004.40.8.850473

15. Rountree SD, Chan W, Pavlik VN, Darby EJ, Siddiqui S, Doody RS. Persistent treatment with cholinesterase inhibitors and/or memantine slows clinical progression of Alzheimer disease. Alzheimers Res Ther 2009;1:7. doi: 10.1186/alzrt7

16. Darvesh S, Martin E, Walsh R, Rockwood K. Differential effects of lipid-lowering agents on human cholinesterases. Clin Biochem 2004;37:42-9. doi: 10.1016/j. clinbiochem.2003.09.004

17. Cibicková L, Palicka V, Cibicek N, Cermáková E, Micuda S, Bartosová L, Jun D. Differential effects of statins and alendronate on cholinesterases in serum and brain of rats. Physiol Res 2007;56:765-70. PMID: 17087598

18. Macan M, Vukšić A, Žunec S, Konjevoda P, Lovrić J, Kelava M, Stambuk N, Vrkić N, Bradamante V. Effects of simvastatin on malondialdehyde level and esterase activity in plasma and tissue of normolipidemic rats. Pharmacol Rep 2015;67:90713. doi: 10.1016/j.pharep.2015.02.005

19. Kunec-Vajić E, Bernat N, Muacević-Katanec D. Effect of hypolipidemic drugs on cholinesterase activity in the rat. Gen Pharmacol 1992;23:217-9. doi: 10.1016/03063623(92)90013-A

20. Bradamante V, Vrkić N, Lucić A, Radić B, Macan M. Interrelated effects of high sucrose diet and gemfibrozil on butyrylcholinesterase activity and plasma lipids in rats. Period Biol 2005;107:189-93.

21. Muačević-Katanec D, Bradamante V, Reiner Ž, Sučić M, Poljičanin T, Bušljeta I, Metelko Ž. Clinical study on the effect of simvastatin on butyrylcholinesterase activity. Arzneimittel-Forschung 2005;55:271-5. doi: 10.1055/s-0031-1296856

22. Guillen J. FELASA guidelines and recommendations. J Am Assoc Lab Anim Sci 2012;51:311-21. PMCID: PMC3358979

23. Deckardt K, Weber I, Kaspers U, Hellwig J, Tennekes H, van Ravenzwaay B. The effects of inhalation anaesthetics on common clinical pathology parameters in laboratory rats. Food Chem Toxicol 2007;45:1709-18. doi: 10.1016/j. fct.2007.03.005

24. Ellman GL, Courtney KD, Andres V, Feather-Stone RM. A new rapid colorimetric determination of acetycholinesterase activity. Biochem Pharmacol 1961;7:88-95. doi: 10.1016/0006-2952(61)90145-9

25. Rowe P. Essential Statistics for the Pharmaceutical Sciences. $2^{\text {nd }}$ ed. Chichester: Wiley-Blackwell; 2007.

26. Cibicková L, Hyspler R, Micuda S, Cibicek N, Zivna H, Jun D, Ticha A, Brcakova E, Palicka V. The influence of simvastatin, atorvastatin and high-cholesterol diet on 
acetylcholinesterase activity, amyloid beta and cholesterol synthesis in rat brain. Steroids 2009;74:13-9. doi: 10.1016/j. steroids.2008.08.007

27. Dalla Y, Singh N, Jaggi AS, Singh D. Memory restorative role of statins in experimental dementia: an evidence of their cholesterol dependent and independent actions. Pharmacol Rep 2010;62:784-96. doi: 10.1016/S1734-1140(10)70339-X

28. Butler EG, England PJ, Williams GM. Effect of peroxisome proliferating hypolipidemic agents on serum activity levels of arylesterase and cholinesterase in rats and mice. Res Commun Chem Pathol Pharmacol 1988;60:125-8. PMID: 3381006

29. Hashimoto F, Ishikawa T, Hamada S, Hayashi H. Effect of gemfibrozil on lipid biosynthesis from acetyl-CoA derived from peroxisomal beta-oxidation. Biochem Pharmacol 1995;49:1213-21. doi: 10.1016/0006-2952(95)00041-W

30. Sisková K, Bilka F, Adameová A, Balazová A, Mydla M, Pauliková I. Influence of lipid imbalance on butyrylcholinesterase activity and biotransformation efficiency. Pharmazie 2012;67:345-50. doi: 10.1691/ ph.2012.1653

31. Martin G, Duez H, Blanquart C, Berezowski V, Poulain P, Fruchart JC, Najib-Fruchart J, Glineur C, Staels B. Statininduced inhibition of the Rho-signaling pathway activates PPAR alpha and induces HDL apoA-I. J Clin Invest 2001;107:1423-32. doi: 10.1172/JCI10852

32. Seo M, Inoue I, Ikeda M, Nakano T, Takahashi S, Katayama S, Komoda T. Statins activate human PPAR alpha promoter and increase PPAR alpha mRNA expression and activation in HepG2 cells. PPAR Res 2008;2008:316306. doi: $10.1155 / 2008 / 316306$

33. Oliveira AC, Bertollo CM, Rocha LT, Nascimento EB Jr, Costa KA, Coelho MM. Antinociceptive and antiedematogenic activities of fenofibrate, an agonist of PPAR alpha, and pioglitazone, an agonist of PPAR gamma. Eur J Pharmacol 2007;561:194-201. doi: 10.1016/j.ejphar.2006.12.026

34. Roglans N, Sanguino E, Peris C, Alegret M, Vázquez M, Adzet T, Díaz C, Hernández G, Laguna JC, Sánchez RM. Atorvastatin treatment induced peroxisome proliferatoractivated receptor alpha expression and decreased plasma nonesterified fatty acids and liver triglyceride in fructose-fed rats. J Pharmacol Exp Ther 2002;302:232-9. doi: 10.1124/ jpet.302.1.232

35. Grabacka M, Pierzchalska M, Dean M, Reiss K. Regulation of ketone body metabolism and the role of PPAR $\alpha$. Int J Mol Sci 2016;17:2093. doi: 10.3390/ijms 17122093

36. Grygiel-Górniak B. Peroxisome proliferator-activated receptors and their ligands: nutritional and clinical implications - a review. Nutr J 2014;13:17. doi: 10.1186/14752891-13-17

37. Ferreira AV, Menezes-Garcia Z, Mario EG, Delpuerto HL, Martins AS, Botion LM. Increased expression of oxidative enzymes in adipose tissue following PPAR $\alpha$-activation. Metabolism 2014;63:456-60. doi: 10.1016/j. metabol.2013.12.009

38. Kallai-Sanfacon MA, Cayen MN, Dubuc J, Greselin E, Dvornik D. Effect of AY-25,712 and other lipid-lowering agents on liver catalase and liver carnitine acetyltransferase in rats. Proc Soc Exp Biol Med 1983;173:367-71. doi: 10.3181/00379727-173-41658

39. Harano Y, Yasui K, Toyama T, Nakajima T, Mitsuyoshi H, Mimani M, Hirasawa T, Itoh Y, Okanoue T. Fenofibrate, a peroxisome proliferator-activated receptor alpha agonist, reduces hepatic steatosis and lipid peroxidation in fatty liver Shionogi mice with hereditary fatty liver. Liver Int 2006;26:613-20. doi: 10.1111/j.1478-3231.2006.01265.x

40. Roy A, Pahan K. PPAR $\alpha$ signaling in the hippocampus: crosstalk between fat and memory. J Neuroimmune Pharmacol 2015;10:30-4. doi: 10.1007/s11481-014-9582-9

41. Lizard G, Rouaud O, Demarquoy J, Cherkaoui-Malki M, Iuliano L. Potential roles of peroxisomes in Alzheimer's disease and in dementia of the Alzheimer's type. J Alzheimers Dis 2012;29:241-54. doi: 10.3233/JAD-2011-111163

42. Berger J, Dorninger F, Forss-Petter S, Kunze M. Peroxisomes in brain development and function. Biochim Biophys Acta 2016;1863:934-55. doi: 10.1016/j.bbamcr.2015.12.005

43. Pytel E, Bukowska B, Koter-Michalak M, OlszewskaBanaszczyk M, Gorzelak-Pabiś P, Broncel M. Effect of intensive lipid-lowering therapies on cholinesterase activity in patients with coronary artery disease. Pharmacol Rep 2017;69:150-5. doi: 10.1016/j.pharep.2016.09.016

\section{Učinci simvastatina i fenofibrata na aktivnost butirilkolinesteraze u mozgu, plazmi i jetri normolipidemičnih i hiperlipidemičnih štakora}

Cilj ispitivanja bio je u normolipidemičnih i hiperlipidemičnih štakora potvrditi pretpostavku da simvastatin (SIMV) i fenofibrat (FENO) ne uzrokuju samo povećanje aktivnosti butirilkolinesteraze (BuChE) u plazmi i jetri nego i povećavaju aktivnosti BuChE u mozgu. Katalitička aktivnost enzima mjerena je upotrebom acetiltiokolina (ATCh) i butiriltiokolina (BTCh) kao supstrata. Normolipidemični i hiperlipidemični štakori raspoređeni su u eksperimentalne skupine, koje su tri tjedna primale SIMV $50 \mathrm{mg} / \mathrm{kg}$ na dan ili FENO $30 \mathrm{mg} / \mathrm{kg}$ na dan, dok su kontrolne skupine primale fiziološku otopinu. I SIMV i FENO uglavnom su izazvali povećanje aktivnosti BuChE u mozgu obaju sojeva štakora bez obzira na korišteni supstrat. Aktivnosti BuChE mjerene BTCh kao supstratom bile su značajno veće u odnosu na kontrolne vrijednosti u mozgu normolipidemičih štakora nakon primjene SIMV te u mozgu hiperlipidemičnih štakora nakon primjene obaju agensa $(14-17 \%, p<0,001)$. Povećanje aktivnosti BuChE u plazmi i jetri nakon primjene SIMV i FENO izmjeren je u oba soja štakora bez obzira na to je li korišten ACTh ili BTCh. U većini slučajeva povećanje aktivnosti BuChE u plazmi i jetri bilo je značajno. S obzirom na važnu ulogu BuChE u kolinergičnom prijenosu te na njezinu farmakološku funkciju, potrebno je nastaviti istraživanja utjecaja antilipidnih lijekova na aktivnost BuChE. 